\title{
Beyond NAFTA with Three Countries: The Impact of Global Value Chains on an Outdated Trade Agreement
}

\author{
Michèle Rioux ${ }^{1}$, Mathieu Ares ${ }^{2}$, Ping Huang3 \\ ${ }^{1}$ Département de science politique, Université du Québec à Montréal, Montreal, Canada \\ ${ }^{2}$ École de politique appliquée, Université de Sherbrooke, Sherbrooke, Canada \\ ${ }^{3}$ Center for Research on Integration and Globalization, Montreal, Canada \\ Email: rioux.michele@uqam.ca, Mathieu.Ares2@USherbrooke.ca, huang.ping@uqam.ca
}

Received 28 January 2015; accepted 16 June 2015; published 19 June 2015

Copyright (C) 2015 by authors and Scientific Research Publishing Inc.

This work is licensed under the Creative Commons Attribution International License (CC BY). http://creativecommons.org/licenses/by/4.0/

(c) (i) Open Access

\section{Abstract}

This article shows how the North American Free Trade Agreement (NAFTA) is significantly affected by the redeployment of transpacific specialized value chains and production networks. More specifically, our study looks at the repositioning of NAFTA partners with new transnational production networks which point to the need for new trading schemes redeploying regional strategies on the transpacific axis. We used the ICT sector as an empirical case showing how China had become a key partner for the three NAFTA partners. This suggests changes in the process of regional economic integration/disintegration. Yet, a closer look at the global value chain of Apple indicates that US enterprises play a pivotal role in this transformation. Our findings point to the fact that the regional integration is significantly affected by emerging transpacific production networks linking the NAFTA regional trade pact to a new transpacific economic space. This can help explain the importance for the three countries to negotiate transpacific trade agreements like the Transpacific Trade Partnership which can be viewed as a de facto renegotiation of NAFTA, 20 years after its emergence as a regional trading model.

\section{Keywords}

Regional Integration, Global Value Chains, Trade, Governance, NAFTA

\section{Introduction}

North America emerged in the 1990s as a very strong and influential regional model of integration (Robert,

How to cite this paper: Rioux, M., Ares, M., \& Huang, P. (2015). Beyond NAFTA with Three Countries: The Impact of Global Value Chains on an Outdated Trade Agreement. Open Journal of Political Science, 5, 264-276. 
2000; Rioux \& Deblock, 2010). As such, it brought about new regulatory and strategic instruments deployed at multiple and diversified levels of governance. From the point of view of the US and to a lesser extent from that of Canada, one of the initial and most important objectives of the North American Free Trade Agreement (NAFTA) was to improve the competitiveness of the region by relocating in Mexico, especially in the area of border production, where production functions were low-tech and intensive in terms of labor. This allowed for functions designs, marketing and financing to be located in the US and Canada (Sklair, 1989). Until 2000, this restructuring of the division of labor across North America worked well, but it did not survive the entry of China into the World Trade Organization (WTO) in 2001 because of its low costs advantage (Arès, 2005).

This paper shows how the integration scheme now appears to be significantly affected by the redeployment of transpacific specialized value chains and production networks. If sectors such as clothing have not been able to adapt to this new reality, we observe the dynamism of the North American value chain in the electronics industry, including in the production of information and communications technology (ICT) equipments. If the US and US enterprises still play a pivotal role in this reconfiguration, it is a challenge for NAFTA and its future. It is also a context that enables to explain why the three countries are now increasing involved in negotiations aiming at a TPP rather that to try to renovate NAFTA.

NAFTA, as a very strong integration and regulation model, has spread beyond North America. It was undoubtedly a competitive strategy for the industrial repositioning of Mexico and of North America as a whole. Yet, its impacts are now, twenty years after its birth, very small and significantly overshadowed by the fact that the three countries have multiplied trade and investments agreements with numerous countries. One very important factor and structural element shaping governance and regulation of economic integration in North America is the importance of China for the North American region. The TPP, if successfully negotiated, will transform NAFTA; it is not only another trade agreement but the way that the three countries are looking to negotiate new trade related regulatory issues with a strategic goal in mind which is to make a breakthrough that can deal with interregional issues linked to the development of new global value chains.

In this article, we argue that China has become a powerful and significant partner for the three NAFTA partners, which is changing the rules of the game and the process of economic integration/disintegration within North America. We first look at the transformations and repositioning of the three countries in a very important sector-ICT, highlighting the expanding trade relations with China. Looking at the ICT sector, we then turn to a more micro perspective to highlight new realities of globalization and their structuring impact on trade relations and trade diplomacy. We then discuss the case of Apple and its transpacific value chains to better understand the new competitive environment of electronic value chains. Based on the study of the electronics sector and strategies of Apple, we try to understand the new integrative dynamics of the NAFTA region and the new challenges of integrative regulation. Finally, we will outline important regulatory issues that will shape future economic diplomacy involving enterprises, states and workers. In looking at the interface between NAFTA and Apple strategy, we discover that the global organization of production by Apple is a more determining factor of world industrial structure than anything related to the NAFTA agreement. The future of NAFTA depends on its interregional reshaping through global value chains. In this way, we can thus understand the importance of transpacific negotiations for the three North American countries.

\section{NAFTA and ICT Trade: The Fourth Partner}

NAFTA, 20 years of age, was criticized for its many downfalls and limitations but it was celebrated for the positive economic results for the three partners in the 10 first years of its implementation. It became a model, was replicated and built upon in other trade agreements. Yet, NAFTA today appears to be a politically and economically stalled project. Lack of common purpose and identity, few expansion opportunities later on and limited new joint initiatives explain this situation. But most importantly, the fact is that there are now four players in North America since China has emerged as a key economic partner in the regional, and global, integrative process. China, in less than a decade, became the second trading partner of Canada, the United States and Mexico, dictating the pace and standards of competitiveness (Arès, Deblock, \& Lin, 2011; Dussell Peters \& Gallagher, 2013).

It is undeniable that China has made significant inroads into the market in North America, especially after its accession to the WTO in 2001. As evidenced by large trade deficits of the three NAFTA partners with China, "exclusive" North American value chains are less competitive, with the notable exception of automobile produc- 
tion (Gallagher, Moreno-Brid, \& Porzecanski 2007; Lamadrid et al., 2012) and electronics, and even in the latter case, many components are imported from China. The importance of these sectors-and also of the energy sector-is related to significant intra-North American trade.

We also must note the centrality of Mexico and its re-export sector (maquila) in intra-regional tradeflows, as Mexico specialized in the assembly of components for their re-exports to markets in North America. Monroy Gómez Franco (2014: pp. 3-4) noted that, in 2011, if 81.9\% and 75.6\% of Mexican production of electronic and automotive components are respectively destined for export, these sectors imported, respectively,68.5\% and $45.2 \%$ of their inputs. In fact, this is not an isolated case, global trade in parts, modules and other electronic components now representsat significant share of trade in intermediate goods, 20.3\% of total trade in 2006 (Sturgeon \& Kawakami, 2010: p. 4).

In North American trade, the ICT sector is important. In 2011, this sector recorded 18\% of trilateral trade, nearly 179 billion US dollars (Table 1). Among the priority sub-sectors, we find digital media, computer games, wireless products, and the information technology for health purposes. NAFTA has undoubtedly contributed to the emergence of production and consumption of ICT in North America. Among the most significant changes, there is the emergence of the Mexican ICT industry. Helped by a depreciated currency and low costs of labor, Mexico has recorded an increase in the export of ICT of 56\% between 2001 and 2011, increasing from US $\$ 32,891$ millions to US \$52,404 millions. The United States has consolidated its dominance in the world market as the second largest marketfor imports and the third origin of exports of goods in the ICT equipment sector. In Canada, the ICT industry is an important source of economic activity and employment. In 2011, it accounted for 4.9\% of GDP (Industry Canada, 2012), with some 500,000 employees, representing 3\% of employment (Industry Canada, 2013).

NAFTA countries account for a large proportion of the global ICT equipment market. In 2010, these countries accounted for almost $20 \%$ of imports and $12 \%$ of exports. The United States accounted for over three quarters of imports and around two thirds of the volume of exports of North America (280 billionsUS\$ and 135 billions US\$, respectively). Mexico holds $6 \%$ of global flows of these products, while Canada's contribution amounted to $2.4 \%$ of total volume. This shows that trade is highly polarized on the United States (Table 2).

Even though the ICT sector remains one of the most dynamic sectors of North America, the situation has changed considerably in recent years. We observe a further development of global value chains, with a dual effect on the three countries: the expansion of US domestic production in East Asia and the restructuring of the

Table 1. Exports and imports of global ICT trade, NAFTA countries, 2011 (millions US \$).

\begin{tabular}{ccc}
\hline Canada & Exports & 7984 \\
& Imports & 12,171 \\
Mexico & Exports & 52,404 \\
& Imports & 8981 \\
United States & Exports & 49,483 \\
Total & Imports & 48,606 \\
\hline
\end{tabular}

Source: UNCTAD, data collected and compiled by authors.

Table 2. Exports/Imports of ICT equipments, 2010 (millions US \$).

\begin{tabular}{|c|c|c|c|c|c|c|c|}
\hline Country & Rank & 2010 & Share \% & Country & Rank & 2010 & Share \\
\hline Export & & & & Import & & & $\%$ \\
\hline China & 1 & 459,522 & 26.7 & China & 1 & 284,783 & 15.3 \\
\hline China, Hong Kong & 2 & 176,964 & 10.3 & United States & 2 & 280,074 & 15 \\
\hline United States & 3 & 134,549 & 7.8 & China, Hong Kong & 3 & 188,736 & 10.1 \\
\hline Mexico & 11 & 60,159 & 3.5 & Mexico & 8 & 57,961 & 3.1 \\
\hline Canada & 21 & 10,687 & 0.6 & Canada & 15 & 33,055 & 1.8 \\
\hline
\end{tabular}

Source: UNCTAD, data collected and compiled by authors. 
Mexican and Canadian industry. In 2001, Mexico was the largest supplier of ICT goods in the United States, with $15.7 \%$ market share. Ten years later, almost half of US imports come from China, the value of trade between China and the United States has multiplied by six to reach US \$143 billion. For their part, Canadian and Mexican companies have reoriented investment in value-added sectors, while repositioning in a context of production on a global scale.

In the mid-1980s, the Chinese government decided to revamp its policy regarding ICT technologies to link the defense sector to the civil and economic spheres; the sector is the main strategic pillar of the national economy. Emphasis was placed on the computerization of infrastructures, domestic demand and stimulation of exports. Such restructuring has resulted in a radical change in industrial structure in which ICT has become the leading sector of the national economy. During three decades, the sector has recorded an average annual growth three times as fastthan national GDP growth, at least more than $20 \%$ on average and up to $60 \%$ at its highest level (Ministry of Science and Technology, 2008: p. 4). In 2012, the information technology represented 5.3\% of GDP and generated a turnover of 1814 billion US dollars, of which $22.7 \%$ came from software and $77.3 \%$ from manufacturing. The sector has gathered 16,587 large companies or state-owned enterprises employing 10 million workers ${ }^{1}$. The global share of Chinese exports of ICT goods was multiplied by 6 in the last ten years, from $4.4 \%$ in 2000 to $28.9 \%$ in 2011 (Table 3).

This growth rate has enabled China to become the world's largest exporter. In 2010, China became also the largest importer, a place that had been occupied before by the United States. In 2012, the volume of exports and imports from China reached 1.18 trillion US dollars (1180 billion US \$), or 30.7\% of total foreign trade (MIIT, 2013). This can be explained largely by the fact that China plays a fundamental role in the global production value chain insofar as it is the main destination for ICT exports in the region. Roughly $64 \%$ of imports in China for re-export originate fromEast Asian countries such as Japan, South Korea, or ASEAN countries, etc. (Thorbecke, 2010).

Trade of ICT goods from China to NAFTA grew by 360\% between 2000 and 2011, reaching nearly \$US 154 billion, representing $25.7 \%$ of world trade with the region (US $\$ 598$ billion). As for NAFTA, progress is moderate and varies by country. During the same period, the United States and Mexico have experienced relatively modest growth (14\% and 59\% respectively), with regards to exports of ICT goods in the area while Canada has seen the value its exports decrease by more than half (56\%) (Figure 1).

We can see that the dramatic gains in China's trade in ICT goods happened at the expense of North America. Within NAFTA, Canada is in last place in terms of manufacturing of ICT (Figure 2). The bursting of the technology bubble in 2000 and the fall of the Canadian telecommunications giant Nortel led to a degradation of the manufacturing industry in Canada. From 2000 to 2003, the volume of exports decreased by 240\%. It must be noted though that Canada specializes increasingly in the software and ITC services which represented $61 \%$ of revenue of the ICT sector in 2011 (Industry Canada, 2012).

With regards to exports of ICT goods, the dependence of Canada and Mexico on the market of the United States decreased slightly, although it remains their main destination. In 2001, the U.S. market monopolized $81.49 \%$ of Canadian exports regarding ICT products. In 2012, it had significantly decreased to 63.31\%. In terms of imports, the United States saw their share of the Canadian market shrink to almost half (46.4\%) in 10 years, corresponding to the value of Chinese gains (Table 4). A similar phenomenon was also observed for the imports from Mexico (57.4\% to $14.2 \%)$.

In this perspective, China might stand as one of the largest global "hub" of the ICT sector (Lejour et al., 2012). Yet, the Chinese development model has generated lively debate about its supply-chain strategy. Criticisms

Table 3. ICT goods, Exports, China, US \$ billion and share of world trade (\%).

\begin{tabular}{cccccccccccccc}
\hline & $\mathbf{2 0 0 0}$ & $\mathbf{2 0 0 1}$ & $\mathbf{2 0 0 2}$ & $\mathbf{2 0 0 3}$ & $\mathbf{2 0 0 4}$ & $\mathbf{2 0 0 5}$ & $\mathbf{2 0 0 6}$ & $\mathbf{2 0 0 7}$ & $\mathbf{2 0 0 8}$ & $\mathbf{2 0 0 9}$ & $\mathbf{2 0 1 0}$ & $\mathbf{2 0 1 1}$ \\
\hline China & 44.1 & 53.2 & 78.2 & 121.4 & 177.7 & 234.1 & 297.7 & 358 & 396.4 & 356.3 & 459.5 & 508 & 17.5 \\
World & 998.08 & 873.07 & 896.46 & 1013.82 & 1129.83 & 1378.54 & 1580.17 & 1585.24 & 1637.68 & 1409.55 & 1726.58 & 1803.17 \\
\% & 4.4 & 6.1 & 8.7 & 12 & 15.7 & 17 & 19.7 & 22.6 & 24.2 & 25.3 & 26.6 & 28.2 \\
\hline
\end{tabular}

Source: UNCTAD, data collected and compiled by authors on April 2014.

${ }^{1}$ Statisticsonly include State-Owned Companies (SOE) or those non-state companies having an annual income over \$3.3 million, called "above scale firm”. The ICT sector represents 3.5\% of all companies in this category (out of a total of 325,753 companies). Source: National Bureau of Statistics of China, State Intellectual property office of the P. R. C. 


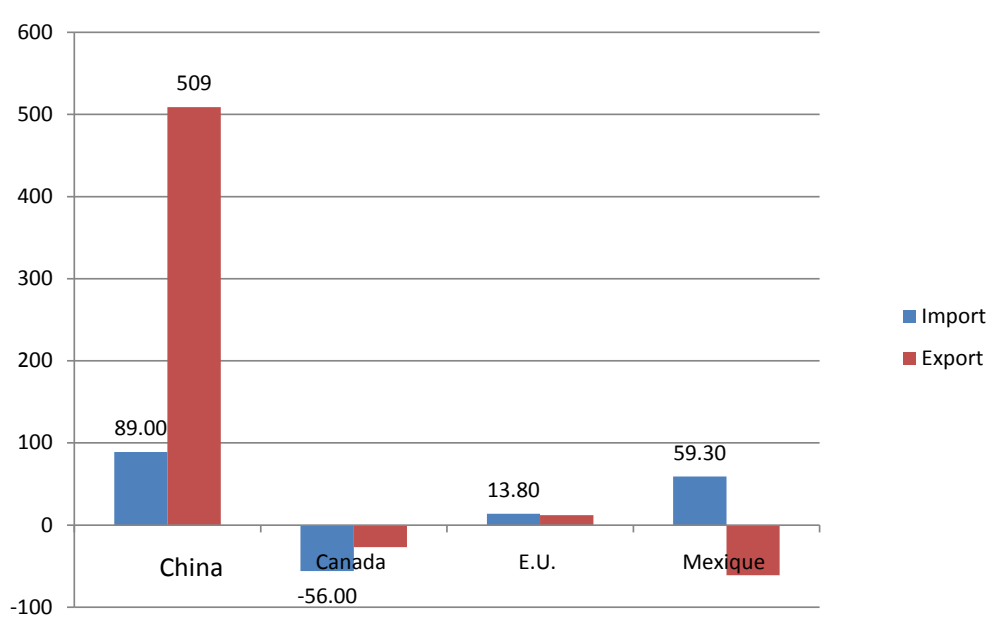

Figure 1. Variation of exports/imports of ICT goods, 2000 and 2011 (\%). Source: UNCTAD, data collected and compiled by authors in April 2014.

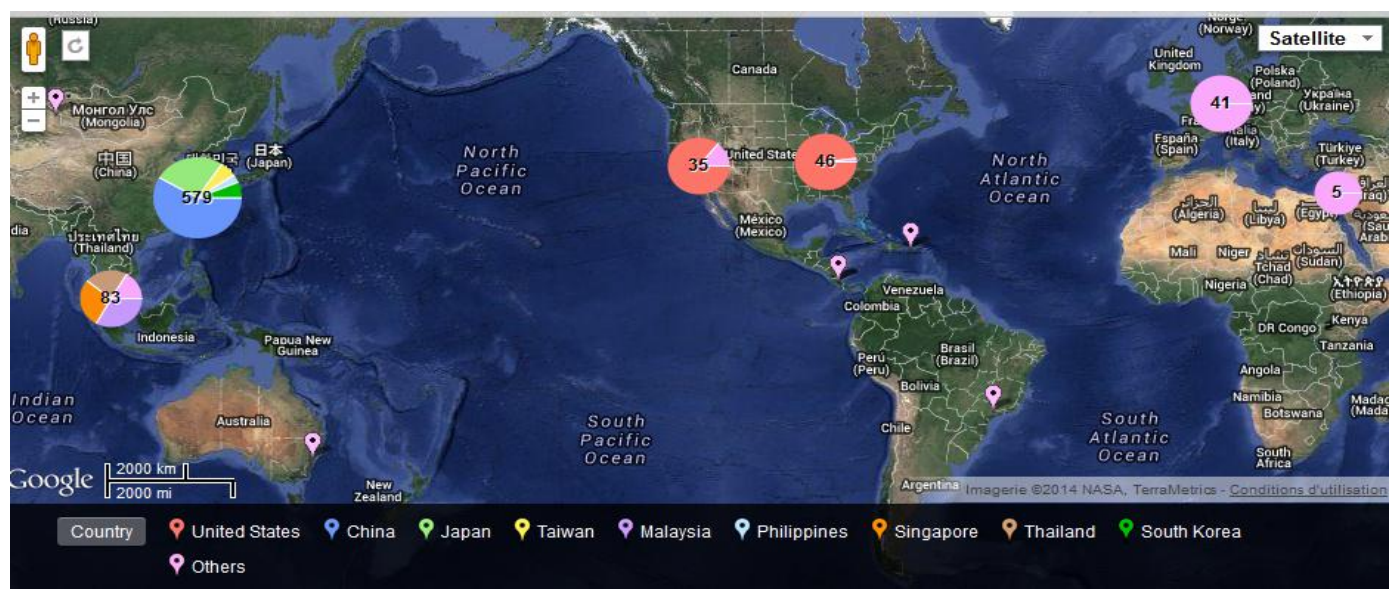

Figure 2. Apple suppliers. Source: China file, based on the Supplier List 2013 of Apple Inc.

highlight its strong external vulnerability to the location choice of global firms because China's success is dependent on its massive access to unskilled labor and on economic conditions abroad (Ma \& Van Assche, 2009). At the same time, low labor costs contributes little to the final value of the products, as compared to the value added during the phases of development and commercialization ${ }^{2}$.

Others, however, argue that international trade and foreign direct investment have facilitated China to upgrade its export patterns, moving from low-cost to "relatively high-value activities in global production networks" (Gereffi, 2005: p. 171). As Gereffi (2009) demonstrates the changes in China's export composition to the United States are significant: from 2/3 of export made up by light consumer goods (i.e. apparel, footwear, toys) in the early 1990s to 40\% of high-technology of China's overall exports to the US in 2006. FDI supported by Chinese government policies has brought, with the capital resources inflows, advanced technology know-how into the country, and has made China a leading destination for research and development facilities for large multinational corporations (Freeman, 2005). It helps not only stimulate institutional and technological innovation in state-owned enterprises, but also spur local entrepreneurs and companies to invest in technology-intensive sectors (e.g. Huawei, Alibaba, and Xiaomi). Whereas the country, during the last decade, occupied the last link in the

\footnotetext{
${ }^{2}$ Xing \& Detert (2011: p. 5) estimated only US \$6.50 of value added in 2009 in China for the iPhone, approximately 3.6\% of the manufacturing cost (i.e. US $\$ 178$, shipping price)). The traditional method of evaluating the volume of trade, not based on the national value-added gives a false picture of trade flows. According to them, while official data for 2009 indicates that China exports nearly US \$2 G. to the United States, the method of national value added rather indicates the multiple sources that better reflects the global value chain (the contribution of Germany (US \$326 M), Japan (US \$670 M), Korea (US \$259 M), other countries (US \$542 M) and even the contribution of the United States (US \$108 M) are superior to that of China (US \$95 M).
} 
Table 4. Bilateral trade ICT goods, Canada, Mexico, US and China (\% of total). Source: Industry Canada, UNCTAD, data collected and compiled by authors in April 2014.

\begin{tabular}{cccc}
\hline Canada & United States & Mexico & China \\
\hline Exports 2001 & 81.49 & 0.51 & 1.2 \\
Exports 2012 & 63.31 & 2.52 & 3.97 \\
Imports 2001 & 50.42 & 6.53 & 5.45 \\
Imports 2012 & 27 & 11.31 & 35.34 \\
Mexico & United States & Canada & China \\
Exports 2001 & 91.2 & 1.3 & 0.7 \\
Exports 2011 & 84.4 & 3.9 & 0.7 \\
Imports 2001 & 57.4 & 0.8 & 4.6 \\
Imports 2011 & 14.2 & 0.6 & 43.7 \\
United States & Mexico & Canada & China \\
Exports 2001 & 13.6 & 14.2 & 7 \\
Exports 2011 & 21 & 14.2 & 11.6 \\
Imports 2001 & 15.6 & 5.4 & 13.4 \\
Imports 2011 & 15 & 1.7 & 49.5 \\
\hline
\end{tabular}

pan-Asian value-chains and transnational production networks, which combine both advanced techniques, intra and inter-industry, direct investment and national specialization in the different phases of production (Ma \& Van Assche, 2011; WTO, 2011), studies show that China's technological upgrade has facilitated China's integration in regional development and its increasing share of word traderelative to its regional neighbors, such as Taiwan. There was a move from "Made in China” to "Made by China” (Barclays, 2014), as demonstrated by the recent growth of Chinese companies in the global firms' suppliers’ list.

\section{Apple and Its Transpacific Value-Chain}

Global companies play a central role in the creation of value chains. Their strategic choices dictate the phases of production, localization of functions, the technological curve, technical standards and distribution conditions, and on this basis, job creation, investment and activity as well as national income. A global value chain describes all activities required to get a product or service from its conception to its end use, and they are distributed geographically (Sydor, 2011: p. 1). Based on their strategic dimension, we often distinguish between two types of value chain models even though they are not mutually exclusive. On the one hand, we find low technologically intensive value chains based on cost control, in for example textile production. On the other, we find the value chain focused on control of a particular technology, as is the case in the electronics industry (OECD 2012: p. 8).

Looking at the global value chain of Apple can help us better understand the transformation of production and integration in North America. Due to the massive use of electronic equipment for leisure and work, the size of the production sector of electronic equipment now compares with the automotive industry. It is very diverse, inasmuch as production of goods for consumers (telephones, televisions, computers, etc.) represent just over half of the fabrication (53\% in 2008). It is also relatively well distributed geographically between Europe (22\% in 2008), North America (22\%), Japan (15\%), China (26\%) and other countries of Asia-Pacific (16\%) (Decision Studies Council, 2009: pp. 5-6). However, if the growing importance of Asia in the electronic value chain is undeniable, the United States and Mexico occupy places among the fifteen largest importers and exporters of electronic goods intermediaries, ranking 2nd and 8th respectively in terms of imports and the third and 11th regarding exports (Table 2).

Globally, the production of communication devices is one of the most fragmented industries, when the criterion used is the input from third countries in the production (OECD, 2012: p. 14). This may be partly due to the interconnectivity desired between different devices provided by multiple specialized suppliers as transport costs appear to be a secondary, given the size of goods and the high value derived from technology (OECD, 2012: p. 27). Typically, parent companies, responsible for research and development (R \& D), finance and distribution are concentrated in developed countries, while developing countries specialize in different manufacturing stages, ranging from simple assembly to the manufacturing of strategic components. 
According to the list published in $2013^{3}$, nearly 750 providers are working with Apple. Asia represented $86 \%$ of its global suppliers. Those are mainly in China where 331 sites exist, compared to 81 in North America and 46 Europe (Figure 2). There are companies that specialize in the design and manufacture of electronic and computer components, such as Samsung, LG, Sony, Qualcomm, but also those who provide assembly services by contract, for example Foxconn.

The literature points out the unequal capture of profit among firms in the Apple production networks. Previous work has put emphasis on the imbalance of power between Apple and its suppliers, particularly in the production line of mobile phones (Kraemer et al., 2011). They use quantitative data grouped by supplier's country of origin to measure the difference in profit between the United States and the rest of the production chain. In 2010, for the manufacture of an iPhone 4 with a retail price of US \$549, the US accounted for US \$321 or 58.5\% of the total price for the part of their work, primarily design and marketing, while 4.7\% (US \$26) went to South Korea for the display and memory, 2.4\% (US \$13) are assigned to U.S. suppliers, 1.1\% (US \$6.5) associated with European manufacturers and $0.5 \%$ (US \$3) go to Japan. In terms of labor costs, an amount of US \$10 is paid to Chinese workers for the assembly.

With each new iPhone release, analysts from IHS iSuppli Research conduct examinations of the units. The panorama unveiled contrasts with the myth of "Made in China" since the main part of the iPhone is not manufactured in China. For example, within an iPhone 5 (2012), among the twenty-two main parts (processor, touchscreen, memory, etc.), Japan and the United States are the two main countries of origin of components. It is only through the intermediary of the Foxconn that the participation of China appears (Table 5). We can thus summarize

Table 5. Main components of iPhone 5. Source: IHS iSuppli Research, $2012^{4}$.

\begin{tabular}{|c|c|c|}
\hline Components & Manufacturers & Countries/Provinces \\
\hline Processor & Samsung & South Korea \\
\hline Touchscreen & $\mathrm{LG}$ & South Korea \\
\hline Touchscreen controler & $\begin{array}{l}\text { Broadcom, } \\
\text { Instruments }\end{array}$ & United States \\
\hline Memory, NAND Flash & Sandisk & Japan \\
\hline Memory, SDRAM & Elpida & Japan \\
\hline Camera & Sony & Japan \\
\hline Module WLAN/BT/FM/GPS & Qualcomm & United States \\
\hline Module WLAN/BT/FM/GPS 1 & Elpida & Japan \\
\hline User interface sensor & na & na \\
\hline Module WLAN/BT/FM/GPS 2 & Murata & Japan \\
\hline Energy management & Dialog, Qualcomm & Germany \\
\hline Battery & Sony & Japon \\
\hline Audio codec & Cirrus Logic & United States \\
\hline Audio Amplifier & Cirrus Logic & United States \\
\hline Power Amplifier & Avago & United States \\
\hline Power Amplifier 1 & Skyworks & United States \\
\hline Accelerometer & ST Microelectronics & France, Italy \\
\hline IC Interface & NXP & Taiwan \\
\hline Electronic Compasses & AKM Semiconductor & Japan \\
\hline Front-end module & Murata & Japan \\
\hline Antenna & Skyworks & United States \\
\hline RM Switch & RF Micro & United States \\
\hline Assembly & Foxconn & Taiwan \\
\hline Mechanical/electromechanical & & Others \\
\hline Case & & Others \\
\hline
\end{tabular}

${ }^{3}$ Apple Inc. (2013). Supplier List 2013.

${ }^{4}$ Source: https://technology.ihs.com/411502/many-iphone-5-components-change-but-most-suppliers-remain-the-same-teardown-reveals. 
the production of the iPhone in four steps: 1) product design in the United States; 2) purchase of components among US, Japanese, Korean and European suppliers; 3) assembly of components at Foxconn factories in China; 4) export of finished products worldwide.

Most researchers are looking at the factors that contribute to the success of Apple, particularly its governance model of global value chains (Dedrick et al., 2008, 2011; Kraemer et al., 2011; Linden et al., 2011). Dedrick et al. (2008) referred to the theory Profiting from Innovation developed by Teece (1986) who links the ability of a company to profit from innovation to three main factors, both internal and external: a dominant standard, an intellectual property regime ${ }^{5}$ and complementary assets. They conclude that the main reason Apple's iPod family gets a bigger profit, compared to notebook PC models of Lenovo and Hewlett-Packard (HP), lies in the exclusive control exercised by the company on software constituting the heart of the infrastructure of these products, as well as standards and materials. This exclusive tacit knowledge of industrial design and user interfaces also allows the company to reduce the possibility of imitation by competitors. Apple's innovations have been developed within the system. This approach differs from that adopted by other companies in the sector which continue to follow the structure established by Wintel (Windows and Intel). Apple has put in place arrangements to secure the system of complementary assets such as an exclusive distribution network (Apple stores), the platform for the sale of music and video online (iTunes store), and patented accessories. With the existence of a closed production structure, Apple is a powerful customer, which has the ability to influence the market and suppliers. The high level of profits is a result of a power relation benefitting Apple, insofar as Apple may require its suppliers a low price level or switch to another provider that best meets their needs. Yet, Froud et al. (2014) describe an "apparent paradox between the misery of the assembler and the richness of the brand" (p.54) at the earth of Apple's financialization (...) model. The authors analyzed the different positions of Fox conn and Apple through the value chain. The results show the company struggling to make a profit despite the low cost of its workforce. On Apple's side, the firm has managed to increase its revenue by a factor of 5 from 2005 to 2010.

According to the authors, the situation which China (and its companies) faces today is different from the 1980s and 1990s when Japanese and Korean companies suffered less influence from Western companies. Relationships between Foxconn and Apple are considered similar to those of a subcontractor of the apparel sector that only performs activities "cut, make, trim" (Froud et al., 2012: p. 20). Haslam et al. (2013) add that Apple contracts make up towards 50\% of Foxconn's revenues. This strong dependence makes Foxconn more vulnerable than other suppliers, such as Samsung which has a very different relationship with Apple. This means that Apple value chain power is diverse and evolving power relations exists between Apple and other actors in its production networks.

\section{Good, Bad, or How Relevant for North America Integration Process}

In the report How the iPhone Widens the United States Trade Deficit with the People's Republic of China, Xing \& Detert (2010) indicated that the deficit of the United States attributed to China's exports is due to a measurement problem. Statistics obscure international flows leaving aside indirect trading partners since the U.S. imports from China have a significant portion of products actually manufactured outside the country. They highlighted the fact that in 2009, China accounted for only 3.6\% of value. The remaining $96.4 \%$ thus included $16 \%$ of German products, 34\% of Japanese components, $13 \%$ of South Korean manufacturing, and $0.5 \%$ of American products. As the cost of labor for the assembly of the final products represent only a small portion of the profits for the company, the authors hypothesize that relocation of Chinese assembly plants to the United States could have an impact on reducing US trade deficit but not on the Californian company that could even maintain a profit margin of $50 \%$.

International trade is often associated with job loss. This is however not the case for Apple as highlighted Linden et al. (2011). According to the authors, the dominant position that the company occupies in global value chains and its importance in the process of decision making, allowing it to retain within the United States most of its functions from R \& D, administration and marketing, often well-paid jobs. Estimates made by the authors from multiple resources (business reports, government, interviews, etc.) indicate that in 2006, despite the fact that the iPod value chain employed almost twice the number of people in foreign countries $(27,250)$ as in the United States $(13,920)$, of the employment revenues related iPod valued estimated at more than US \$1 billion, US \$750 million were paid to American workers and US \$320 million were distributed to those working outside

\footnotetext{
${ }^{5}$ See Pisano \& Teece (2007). Proprietary regimes include the strategic aspects which can limit competition in a technology segment and protect firm profits, such as intellectual property rights and industry standards organizations.
} 
the United States. This new dimension of analysis is echoed in the work of Alberro (2011). According to him, in 2006, 36,120 people were involved in the iPod production, taking into account interindustry links and flow of economic transactions resulting from these links.

That is explained by the innovation of Apple in the last years. This turned into some great benefits for the US economy. Apple has adopted an "unconventional” strategy that allows it to achieve "supernormal profits”in a hyper-competitive sector. Yet, Lazonick et al. (2013) point out that Apple’s legendary ability to innovate, contrary to belief, is not sustainable. Referring to the concept of "innovative enterprise", the authors suggest that the evolution of an innovative company is defined by a set of three conditions: 1) strategic control; 2) organizational integration; 3) the financial commitment to innovation (p. 253). Based on the analysis of financial data, the authors show how the importance of these elements by the company has changed over time. As mentioned earlier, leaders predominantly focus on how to extract value created in the past rather than focus on future value. This focus on shareholder value has become much stronger than it was two decades ago.

The authors conclude that Apple ultimately will see the end of innovation. Bergvall-Kåreborn \& Howcroft (2013) analyze the case of mobile phone applications developers with Apple located in Sweden, the United Kingdom and the United States. With this new business model, the applications developed and used for an Apple device can be downloaded from the iTunes store, while sales revenues will be shared between 30\% and $70 \%$ for Apple and its developers. According to the authors, this new business model is not without risk: "The Company relies on third-party intellectual property and digital content, which may not be available to the Company on commercially reasonable terms at all” (p. 284). Montgomerie \& Roscoe (2013) also related the success of Apple with its business model based on an innovation pointing to the integrated platform where content (software, media and applications) and hardware (laptops, phones and tablets) are coupled.

These authors also question the sustainability of the model highlighting the dysfunctional social and economic aspects generated by the fragmentation of value chains of Apple, such as dangerous and inhumane labor practices in China, the challenge of developing new innovative products, the competition from its competitors with respect to the supply chain content, the rivalry between supermarkets and its own stores, etc. Sodhi \& Tang (2013) show that, in the electronics industry, operating margins for the first five subcontractors have been between $2 \%$ and 3\% for the period 2004-2009. Thus, under pressure, subcontractors trying to create and capture value in the supply chain, through measures to reduce production costs, improve quality, acquire foreign brands, invest in research, etc. For example, collaborating with the American company Radio Shack, Foxconn has launched in 2013 an e-market chain in China, targeting high-end electronics and computing products clients. The same year, the company announced the opening of a high-value production plant in Pennsylvania, USA. These strategies adopted by subcontractors cause counter-strategies from Western OEM, such as to diversify contract manufacturers in order to maintain negotiation power. As indicated by Apple's 2013 suppliers' list, the number of Chinese origin companies has increased to sixteen, double the level of $2011^{6}$, including not only batteries suppliers, but also acoustic component companies, such as GoerTek. Such new dealings of the cards could be seen also as the result of, as discussed above, the importance of investment made by state-owned enterprises and private companies in technology-intensive sectors which has resulted in China's upgrade in the global value chains. As Sodhi \& Tang (2013) conclude, Chinese manufacturers and OEMs eventually build relationships that could be win-win: “co-operation, competition, co-opetition” (cooperation and competition at the same time) (p. 23).

The changing complexities of the globalised and financialized business models have implications for integration and governance schemes. The NAFTA region has seen shifting trading relationships increasingly shaped by the global value chain. Some authors affirmed that the relationship between Apple and Foxconn suggests that the outcomes of trans-Pacific supply chain are relevant for national economic development in both China and the USA.

In an earlier generation, it was assumed that 'what was good for GM was good for America'; now Apple’s success largely benefits and is appreciated by investors; and, for its size, Apple's contribution to the domestic economy is limited by its reliance on outsourced assembly. [...] measures of corporate success taken at one point in a chain need to be set in the context of the whole chain. We have shown that FIH (Foxconn) has struggled to use its low labour costs to capture profits and to develop strengths that would allow it to compete in final products, as Japanese and Korean companies have previously done. In conclusion, this analysis serves to high-

6““Chinese companies move into supply chain for Apple components”. Financial Times, September 29, 2013.

http://www.ft.com/cms/s/0/d70fca52-2691-11e3-9dc0-00144feab7de.html\#axzz3OLsaMi00 
light broader questions about the how financialized trans-Pacific supply chains can lead to complex economic and social outcomes, at corporate and national levels (Froud et al., 2014: p. 56).

It is also true for Mexico and Canada. Economic policies and trade and investment governance must take into consideration the volatile characteristic of global value chains where, for example, Japanese suppliers have been replaced by Korean suppliers Samsung and LG in the iPhone and iPads, Apple replaced Silicon Valley chipmaker PortalPlayer with Samsung as the supplier of a key microprocessor. In a globalized industry, most suppliers are at the mercy of decisions by the lead companies in the value chain. Yet this can also be reversed to the benefit of suppliers and this is what could happen to Apple and Samsung. Recent patent disputes between Apple and Samsung illustrate Samsung as a powerful supplier. Apple and Samsung, the two leading smartphone companies have entered to a series of patent battles. However, the Korean giant turns out to be one of Apple's critical component suppliers, producing processors, displays and memory chips. In 2011, it took a part of $7 \%$ gross profits of the sales price for the iPhone and iPad (Kraemer et al., 2011). In the case of iPhone 4S, $12.4 \%$ of the smartphone's materials were Samsung-built ${ }^{7}$. Apple, in turn, is looking to widen its supply chain. For example, it has shifted some purchases away from Korea by picking Japan's Sandisk and Elpida to supply NAND and SDRAM chips. Even Apple's components orders from Samsung have fallen over last years, but it remains critically dependent on Samsung for some key components, for example, the processors and high-resolution screen. According to ZDNet Asia Report, 5.2 million of 9.7 inch Retina displays were shipped to Apple in the first quarter of 2014, a significant increase compared to $2013^{8}$.

To quote Haslam et al. (2013) on relative power of Samsung:

The power that Apple has over its global supply chain is variable and contingent rather than uniform in nature, and we refer to these relationships to argue that Apple's financial transformation is commendable, yet precarious. [...] Samsung was described as Apple's "frenemy" after the recent legal disputes over intellectual property and designs. (...) (p. 277).

Yet, according to data from the International Data Corporation (IDC), in Q4 2014, Apple captured a record 99.7 percent unit growth in China, Year-on-Year, resulting in a boost in its market share from 7.4 percent to 12.3 percent in that period. By comparison, Samsung saw a drop by 49.9 percent, resulting in a decline in market share from 18.8 percent (Q4 2013) to 7.9 percent $^{9}$. One of the reasons for this spectacular success is the agreement reached between Tim Cook and China Mobile by the end of 2013. After six long years of negotiation, this agreement opened the doors for iPhone to the world's biggest mobile phone operator.

Concerns over the effect of overreaching intellectual property litigations between Apple and Samsung on product innovation and development, and on consumers, have been raised by some professionals and academics who fear Apple has used its monopoly to create exit barriers for users, and to shut down competitors that tried to create products patterned after iPad and iPhone perhaps better or cheaper (Cusumano, 2013; Garg, 2013). In industry, particularly in ICT sectors, innovation strategies play a significant role in companies' competitive strategies. Patent holders may convert their exclusive rights into weapons to eliminate their competitors in order to dominate the market (Paik \& Zhu, 2013). In it is that context that intellectual property protection has become a centerpiece of the ongoing TPP negotiation.

It is reported that US is seeking more stringent intellectual property rights (IPR) than provided in earlier trade agreements (Petri et al., 2011). However, US IPR demands have encountered resistance from the treaty partners, not only traditional IP importers, but also from exporters, who fear the United States is trying to impose its own copyright and patent regulations on the treaty in order to protect its business and companies that are major beneficiaries of worldwide intellectual property payments ${ }^{10}$. Even Canada emerged as an anopponent ${ }^{11}$ and many legal scholars have reacted with alarm: "(TPP would create) the most extreme, anti-consumer and anti-development international instrument on intellectual property to date" (Gordon, 2012: p. 20). Innovation and IPR regimes remain a major challenge for future trans-pacific production network and TPP negotiations, which will

\footnotetext{
${ }^{7}$ Source: Apple insider, July 19, 2012.

http://appleinsider.com/articles/12/07/19/made_in_america_apples_supply_chain_increasing_us_production

${ }^{8}$ Source: Zdnet, May 9, 2014. http://www.zdnet.co.kr/news/news_view.asp?artice_id=20140509143908\&type=xml\&

${ }^{9}$ In Q4 2014, Samsung registered 75.1 million handsets shipment, closely followed by Apple with 74.5 million smartphones and $19.85 \%$ of market share. Source: IDC Asia/Pacific Quarterly Mobile Phone Tracker, February 2015.

${ }^{10}$ Intellectual property is a major source of value to the American economy. For example, in 2010, the country captured alone 40 percent of worldwide payments made to intellectual property holders, around US\$100 billion (Gordon, 2012).

${ }^{11}$ Michael Geist. New TPP Leak: Canada Emerges as Leading Opponent of U.S. Intellectual Property Demands. October 16, 2014

http://www.michaelgeist.ca/2014/10/new-tpp-leak-canada-emerges-leading-opponent-u-s-intellectual-property-demands/
} 
shape the conditions of economic development in many countries.

\section{Conclusion}

This article aimed at understanding the impacts of global value chain on regional integration in North America. Regional integration in North America was shaped by NAFTA for a number of years. Yet, a fourth player came on the scene, Asia and especially China. Soon, trade deficits in ICT goods showed a loss of North America in the share of global trade. Yet, if we analyse the global value chain, some evidences from Apple global value chain suggest a very different story line. Rather than losing to Asia, the North American region is now increasingly integrated into transpacific global value chain which is the main vector of integration processes. US global ICT firms such as Apple have been very successful in managing this new situation. Countries, on their parts, are struggling to reinvent their economic policies and trade strategies accordingly. Instead of a ménage a trois, North America is immersed into global value chains where coopetition occurs mainly across the Pacific. Canada and Mexico are being forced to redeploy their policies, taking into account that tremendous change linking globalization and technological innovation. In this new context, we can understand why the three countries are involved in negotiation of a TPP rather than attempting to reinvent NAFTA as an outdated integration model. The world is changing and NAFTA countries must find new rules of the game and strategies to secure the economic and social development of their societies in a globalized and transnational world. NAFTA innovated in many respects as a trade agreement, but the TPP is a trade agreement that might have the same kind of impacts on world economic governance. That is why research should concentrate more on trans-regulatory issues embedded in new trade agreements and their impacts on social and economic development.

\section{References}

Apple Inc. (2013). Suppliers List, 2013.

Arès, M. (2005). Du triomphe à l'inquiétude. L'industrie maquila dans la tourmente. In M. Rioux (Dir.) Globalisation et pouvoirs des entreprises (Chapitre 5). Collection Économiepolitiqueinternationale, Éditions Athéna, Montréal.

Arès, M., Deblock, C., \& Lin, T.-S. (2011). La Chine et l'Amérique latine: Le grand chambardement? In P. Hugon \& J. Marques Pereira (Dirs.), Revue Tiers Monde (pp. 65-82), No. 208, numéro Économie politique tricontinentale: Les nouveaux paradigmes suds-suds.

Barclays (2014). Asia-Pacific Macro Themes Politics behind, EM Asia Looks Ahead.

Bergvall-Kåreborn, B., \& Howcroft, D. (2013). The Apple Business Model: Crowdsourcing Mobile Applications. Accounting Forum, 37, 280-289. http://dx.doi.org/10.1016/j.accfor.2013.06.001

Cusumano, M. (2013). The Apple-Samsung Lawsuits, in Search of a Middle Ground in the Intellectual Property Wars. Communications of the ACM, 55, 28-31. http://dx.doi.org/10.1145/2398356.2398366

Decision Studies Council (2009). World Electronic Industries 2008-2103. Executive Summary, Paris, 15 p.

Dedrick, J., Kraemer, K.-L., \& Linden, G. (2008). Who Profits from Innovation in Global Value Chains? A Study of the iPod and Notebook PCs. Sloan Industry Studies Annual Conference, Boston, 24 April 2008, 34 p. http://dx.doi.org/10.2139/ssrn.1125024

Dedrick, J., Kraemer, K.-L., \& Linden, G. (2011). The Distribution of Value in the Mobile Phone Supply Chain. Telecommunications Policy, 35, 505-521. http://dx.doi.org/10.1016/j.telpol.2011.04.006

Dussell Peters, E., \& Gallagher, K.P. (2013). NAFTA’s Uninvited Guest: China and the Disintegration of North American trade. CEPAL Review, No. 110 (août), 83-108.

Freeman, R. B. (2005). Does Globalization of the Scientific/Engineering Workforce Threaten U.S. Economic Leadership? National Bureau of Economic Research (NBER) Working Paper 11457. http://www.nber.org/papers/w11457

Froud, J., Johal, S., Leaver, A., \& Williams, K. (2012). Apple Business Model Financialization across the Pacific. CRESC Working Paper No. 111, Manchester: Manchester Business School.

Froud, J., Johal, S., Leaver, A., \& Williams, K. (2014). Financialization across the Pacific: Manufacturing Cost Ratios, Supply Chains and Power. Critical Perspectives on Accounting, 25, 46-57. http://dx.doi.org/10.1016/j.cpa.2012.07.007

Gallagher, K. P., Moreno-Brid, J. C., \& Porzecanski, R. (2007). The Dynamism of Mexican Exports: Lost in (Chinese) Translation? World Development, 36, 1365-1380. http://dx.doi.org/10.1016/j.worlddev.2007.08.004

Garg, N. (2013). Apple v. Samsung: Design Protection and Consumers. Pace Intellectual Property, Sports \& Entertainment Law Forum, 3, 115. http://digitalcommons.pace.edu/pipself/vol3/iss1/6 
Gereffi, G. (2005). The Global Economy: Organization, Governance, and Development. In N. J. Smelser, \& R. Swedberg (Eds.), The Handbook of Economic Sociology (pp. 160-182). Princeton, NJ: Princeton University Press and Russell Sage Foundation.

Gereffi, G. (2009). Development Models and Industrial Upgrading in China and Mexico. European Sociological Review, 25, 37-51. http://dx.doi.org/10.1093/esr/jcn034

Gordon, B. K. (2012). Trading Up in Asia. Why the United States Needs the Trans-Pacific Partnership. Foreign Affairs, 91, $17-22$.

Haslam, C., Tsitsianis, N., Andersson, T., \& Yin, Y.-P. (2013). Apple’s Financial Success: The Precariousness of Power Exercised in Global Value Chains. Accounting Forum, 37, 268-279. http://dx.doi.org/10.1016/j.accfor.2013.05.001

Industry Canada (2012). Produit intérieur brut (PIB) du secteur des TIC. http://www.ic.gc.ca/eic/site/ict-tic.nsf/fra/h_it05864.html

Industry Canada (2013). Profil du secteur Canadien des TIC. http://www.ic.gc.ca/eic/site/ict-tic.nsf/fra/h_it07229.html

Kraemer, K.-L., Linden, G., \& Dedrick, J. (2011). Capturing Value in Global Networks: Apple’s iPad and iPhone. PCIC Working Paper.

Lamadrid, P. G., Martínez, S., Salazar, A., Martínez, F., \& Nañez, H. (2012). Ventaja comparativa del sector automotor de México. Comercio Exterior, Sept-Oct, 43-54.

Lazonick, W., Mazzucato, M., \& Tulum, O. (2013). Apple’s Changing Business Model: What should the World’s Richest Company Do With All Those Profits?.Accounting Forum, 37, 249-267. http://dx.doi.org/10.1016/j.accfor.2013.07.002

Lejour, A., Rojas-Romagosa, H., \& Veenedaal, P. (2012). Identifying Hubs and Spokes in Global Supply Chains Using Redirected Trade in Valued Added. CPB Discussion Paper No. 227, CPB Netherlands Bureau for Economic Policy Analysis, La Haye.

Linden, G., Kraemer, K.-L., \& Dedrick, J. (2011). Innovation and Job Creation in a Global Economy: The Case of Apple’s iPod. Journal of International Commerce and Economics, 3, 223-239.

Ma, A. C., \& Van Assche, A. (2009). China's Trade in Crisis. Montréal: HEC Montréal,

Ma, A. C., \& Van Assche, A. (2011). Le rôle de la Chine dans les réseaux de productions mondiaux. In A. Sydor (Dir.), Les chaînes de valeurmondiales: Impacts et implications (pp. 153-190). Les Recherche en Politique Commerciale, Affaires Étrangères et Commerce International Canada, Ottawa: Ministre des Travaux Publics et Services Gouvernement aux Canada, cat. FR2-5/2011F.

Ministry of Industry and Information Technology of the People’s Republic of China (MIIT) (2013). 2012 年电子信息产业 统计公报 (Translation: Statistical Bulletin of the Electronic Information Industry in 2012).

http://www.miit.gov.cn/n11293472/n11293832/n11294132/n12858387/15173031.htm

Ministry of Science and Technology (2008). 中国信息通信技术(ICT)发展报告 (translation: Report on ICT Development in China). http://in.chineseembassy.org/chn/kj/P020080725507009846161.ppt

Monroy Gómez Franco, L. Á. (2014). México: El contenido importado en los principales sectores exportadores. Comercio Exterior, 64, 2-5.

Montgomerie, J., \& Roscoe, S. (2013). Owning the Consumer-Getting to the Core of the Apple Business Model. Accounting Forum, 37, 290-299. http://dx.doi.org/10.1016/j.accfor.2013.06.003

OECD (2012). Mapping Global Value Chains. TAD/TD/WP/RD, 9, Paris.

Paik, Y., \& Zhu, F. (2013). The Impact of Patent Wars on Firm Strategy: Evidence from the Global Smart Phone Market. Working Paper 14-015, Boston, MA: Harvard Business School.

Petri, P. A., Plummer, M. G., \& Zhai, F. (2011). The Trans-Pacific Partnership and Asia-Pacific Integration: A Quantitative Assessment. East-West Center Working Paper, Economics Series No. 119.

Pisano, G. P., \& Teece, D. J. (2007). How to Capture Value from Innovation: Shaping Intellectual Property and Industry Architecture. California Management Review, 50, 278-296. http://dx.doi.org/10.2307/41166428

Rioux, M., \& Deblock, C. (2010). NAFTA—A Model Running Out of Breath? CESifo Forum, 11, 9-16.

Robert, M. (2000). Negotiating NAFTA: Explaining the Outcome in Culture, Textiles, Autos and Pharmaceuticals. Toronto: University of Toronto Press.

Sklair, L. (1989). Assembly for Development: The Maquila Industry in Mexico and the United States. New York: Routledge.

Sodhi, M. S., \& Tang, C. S. (2013). Strategies and Tactics of Chinese Contract Manufacturers and Western OEMs (20012011). International Journal of Production Economics, 146, 14-24. http://dx.doi.org/10.1016/j.ijpe.2012.10.014

Sturgeon, T., \& Kawakami, M. (2010). Global Value Chains in the Electronics Industry. Policy Research Working Paper No. 5417, WPS5417, Washington DC: The World Bank. 
Sydor, A. (2011). Sommaire du rédacteur. Les chaînes de valeur mondiales : impacts et implications. In A. Sydor (Dir.), Les chaînes de valeur mondiales: Impacts et implications (pp. 1-20). Les Recherche en Politique Commerciale, Affaires Étrangères et Commerce International Canada, Ottawa: Ministre des Travaux Publics et Services Gouvernement aux Canada, cat. FR2-5/2011F.

Teece, D. J. (1986). Profiting from Technological Innovation. Research Policy, 15, 285-305. http://dx.doi.org/10.1016/0048-7333(86)90027-2

Thorbecke, W. (2010). How Would an Appreciation of the Yuan Affect the People's Republic of China's Surplus in Processing Trade? Asian Development Bank Institute.

WTO (World Trade Organization) (2011). Trade Patterns and Global Value Chains in East Asia: From Trade in Goods to Trade in Tasks. Genève: WTO Secretariat.

Xing, Y.-Q., \& Detert, N. (2010). How the iPhone Widens the United States Trade Deficit with the People's Republic of China. ADBI Working Paper 257, Tokyo: Asian Development Bank Institute. http://www.adbi.org/working-paper/2010/12/14/4236.iphone.widens.us.trade.deficit.prc

Xing, Y.-Q., \& Detert, N. (2011). How the iPhone Widens the United States Trade Deficit with the People’s Republic of China. Journal Aussenwirtschaft (The Swiss Review of International Economic Relations), 339-350. 